\title{
CYTOKINE MECHANISMS FOR EARLY PERIOD OF EXPERIMENTAL BACTERIAL-IMMUNE PERIODONTITIS DEVELOPMENT
}

\begin{abstract}
Summary. The article presents the results of research on the parameters of cytokine profile as mediator of immune defense, which was determined by the level of proinflammatory and anti-inflammatory cytokines in blood serum of intact animals and on the $7^{\text {th }}$ day of the experimental bacterial-immune periodontitis development. Attention is drawn to the characteristic change in the indicators of the cytokine link of immunity at the early stage of the development of the experimental periodontitis. Based on these results, it was proved that the formation of the pathological process in the periodontal complex is accompanied by an imbalance in the system of cytokinogenesis for the early period of the inflammatory reaction development, indicating their modulating role in the regulation of the immune-inflammatory response in this modeled pathological process.

The aim of the study - to determine pathogenetic role of cytokinogenesis for early stages of the experimental bacterial-immune periodontitis development.

Materials and Methods. The investigations was performed with use of white, non-breeding, clinically healthy male rats $150-200 \mathrm{~g}$ of weight in conditions of vivarium. Experimental animals were randomly selected and divided into two experimental groups: the group 1 - intact animals, control; the group 2 - animals with an experimental periodontitis on the $7^{\text {th }}$ day. Experimental bacterial-immune periodontitis in experimental animals was caused by introducing into the tissue of the periodontal complex a mixture of microorganisms diluted with egg protein [10]. In order to strengthen the immune response, an injection into the rat's foot of the full Freund's adjuvant was performed at the same time. For further research the blood serum was selected, in that was determined the content of tumor necrosis factor alpha (TNF- $\alpha$ ), interleukin-1 beta (IL-1ß), interleukin-4 (IL-4), interleukin-10 (IL-10).

Conclusion. Formation of experimental periodontitis is accompanied by a complex of pathological changes characterized by reliable progressive increase of proinflammatory cytokines for the early stage of inflammatory reaction development, that prove participation of TNF- $\alpha$ and IL-1 $\beta$ in the periodontal diseases pathogenesis.
\end{abstract}

Key words: bacterial-immune periodontitis; immune system; inflammation; inflammatory cytokines; anti-inflammatory cytokines.

INTRODUCTION According to the WHO, periodontal pathology occupied the second place in the structure of dental diseases and is the main cause of premature teeth loss [1]. Generalized periodontitis develops under the influence of local and general factors, but bacterial is considered the leading [2]. The periodontal pathogens triggers a number of protective reactions, which lead to the development of inflammation [3, 4]. Recent studies have shown the leading role of pro- and antiinflammatory cytokines in regulation of the immune-inflammatory response. Progressive destruction of bone tissue in patients with periodontal disease is associated with a combination of cytokines IL-1 $\beta$, IL-6, TNF- $\alpha$ and prostaglandins E2. These cytokines can activate osteoclastogenesis and bone resorption by osteoclasts. Strengthened migration of macrophages under the influence of cytokines and their constant presence in tissues enhances destructive processes in periodontium [5]. In this case, the degree of resorption of the alveolar bone depends on the severity of the organism immune response to bacterial invasion.

However, the relationship between clinical morphological parameters and mediators of the inflammatory-destructive process in periodontium is insufficiently studied. In the last two decades, progress in the study of factors contributing to the periodontal diseases development has led to a deeper understanding of the complex interaction of various mechanisms of organism immune defense, including both innate and acquired adaptive immunity [6]. Research in this direction has revealed several proinflammatory cytokines that have been identified as key molecules that contribute to the destruction of periodontal tissues. This is interleukin-1 (IL-1), tumor necrosis factor alfa (TNF-a), interferon gamma (IFN-y), interleukin 6 (IL-6) [7]. Unlike proinflammatory cytokines, which play an important role in the primary development of inflammatory response in periodontal tissues, anti-inflammatory cytokines inhibit osteoporosis and inhibit macrophage activity, contributing to the relief of inflammatory response in the periodontal complex [8].

The progress in the study of the pathogenetic mechanisms of inflammation development in the periodontal com- plex will be promote better imagine the interconnection between inflammation and immune system, and also allow the introduction of new treatment methods into periodontology, based on the modulating role of cytokines in the regulation of organism immune response [9].

The aim of the study - to determine the pathogenetic role of cytokinogenesis for early stages of the experimental bacterial-immune periodontitis development.

MATERIALS AND METHODS The investigations was performed with use of white, non-breeding, clinically healthy male rats $150-200 \mathrm{~g}$ of weight in conditions of vivarium. The animals were supported on standard diet, balanced by the main nutritional elements. Experiments were carried out in compliance with the general rules and regulations of the European Convention for the Protection of Vertebrate Animals used for research and other scientific purposes (Strasbourg, 1986), the General ethical principles of animal experiments (Kyiv, 2001). Experimental animals were randomly selected and divided into two experimental groups: the group 1 - intact animals, control $(n=10)$; the group 2 - animals with an experimental periodontitis on the $7^{\text {th }}$ day $(n=8)$.

Experimental bacterial-immune periodontitis in experimental animals was caused by introducing into the tissue of the periodontal complex a mixture of microorganisms diluted with egg protein [10]. In order to strengthen the immune response, an injection into the rat's foot of the full Freund's adjuvant was performed at the same time. For further research the blood serum was selected, in that was determined the content of tumor necrosis factor alpha (TNF- $\alpha)$, interleukin-1 beta (IL-1 $\beta$ ), interleukin-4 (IL-4), interleukin-10 (IL-10) by the method Solid-phase enzyme immunoassay using a set of RayBio Rat Cytokine Antibody Array reagents (RayBiotech, Norcross, USA) [11]. The concentration of TNF- $\alpha$, IL-1 $\beta$, IL-4 and IL-10 was expressed in ng / I. The obtained results were statistically analyzed using the software STATISTICA 10.0 ("Statsoft", USA) [12]. The reliability of the difference in values between independent quantitative values 
was determined with the normal distribution by criterion $\mathrm{U}$ criterion Mann-Whitney [13].

RESULTS AND DISCUSSION In a result of our research there was found that content of inflammatory cytokines IL-1 $\beta$, TNF- $\alpha$ in the rat's blood serum with experimental generalized periodontitis was increased significantly as compared with control (Table).

IL-1 $\beta$ belongs to the proinflammatory cytokines of the first line and it is an activator of T-cells, NK-cells, NKT-cells, stimulates the formation of T-cell by cytokines.

In the animals with experimental bacterial-immune periodontitis during the acute phase of the inflammatory process, namely on the $7^{\text {th }}$ day of the study, were found a significant increase in blood serum (by $86.31 \% ; p<0.01$ ) of interleukin$1 \beta$ relative to the control groups (Figure 1 ).

The TNF- $\alpha$ concentration was higher by $66.55 \%(p<0.01)$ in the rat's blood serum on the $7^{\text {th }}$ day of the experiment as compared to the control group of animals (Figure 1). This cytokine as a stimulator of leukocyte activity, production of cells IL-1 $1 \beta$, IL-6 exerts a destructive effect to tissues.

The obtained data as a result of the experiment indicate that changes of proinflammatory cytokines concentration in the rat's blood serum for the early stage of bacterial-immune periodontitis suggests in respect of immune mechanisms restructuring of oral defense in response to the action of pathogens, since the hyperproduction of TNF- $\alpha$ and IL-1 $\beta$ contributes to the enhancement of inflammatory process, damaging the periodontal tissue [14].

As for changes of the proinflammatory cytokines, which included IL-10 and IL-4, then maintenance their in the animal blood in these conditions simulated inflammation is changed in the opposite direction (Table).

In particular, IL-10 belongs to the group of anti-inflammatory cytokines, is an important endogenous regulator of immune and inflammatory processes, which can suppress the activation and function of T-cells, NK-cells, macrophages, and their proinflammatory cytokines [15]. Thus, the content of this interleukin on the $7^{\text {th }}$ day was decreased in the rat's serum blood by $70.24 \%$ $(p<0.01)$ relative to intact animals (Figure 2$)$.

In regard to changes in the content of another anti-inflammatory cytokine IL-4 in the blood serum of experimental animals with periodontitis, it should be noted that on the $7^{\text {th }}$ day of the experiment, its indices were significantly lower (by $40.05 \%, p<0.01$ ) compared to those that were obtained in animals of the control group (Figure 2).

As a result of decrease in the content of anti-inflammatory and an increase in the content of proinflammatory cytokines in the blood serum of experimental animals, cytokine imbalance arose, as evidenced by a violation of their ratio (IL-1ß / IL-10).

As compared the ratio of IL-1 / IL-10 in blood serum of experimental animals, it was found that it was significantly prevalent in rats with experimental bacterial-immune inflammation in the periodontal complex on the $7^{\text {th }}$ day (by $550.00 \%$; $\mathrm{p}<0.01$ ), compared to the control group (Figure 3).

Thus, our experimental data indicate to implication of proinflammatory and anti-inflammatory cytokines in the pathogenesis of inflammatory reaction in the periodontal complex.

CONCLUSIONS 1. Formation of experimental periodontitis is accompanied by a complex of pathological changes

Table. The content of cytokines in blood serum of experimental animals for early period of experimental periodontitis development $(\mathrm{M} \pm \mathrm{m})$

\begin{tabular}{|c|c|c|}
\hline The form of the experiment & Control, intact animals & White rats with experimental periodontitis \\
\hline Experiment duration (days) & - & 7 \\
\hline Number of the animals & 10 & 8 \\
\hline IL-1 $\beta, \mathrm{ng} / \mathrm{I}$ & $8.40 \pm 0.51$ & $\begin{array}{c}15.65 \pm 0.50 \\
p<0.01\end{array}$ \\
\hline TNF- $\alpha$, ng / I & $25.80 \pm 0.51$ & $\begin{array}{c}42.97 \pm 0.70 \\
p<0.01\end{array}$ \\
\hline IL-10, ng / I & $71.06 \pm 2.96$ & $\begin{array}{c}21.15 \pm 2.11 \\
p<0.01\end{array}$ \\
\hline IL-4, ng / I & $20.05 \pm 1.04$ & $\begin{array}{c}12.02 \pm 0.60 \\
p<0.01\end{array}$ \\
\hline IL-1 / IL-10 & $0.12 \pm 0.01$ & $\begin{array}{c}0.78 \pm 0.06 \\
p<0.01\end{array}$ \\
\hline
\end{tabular}

Notes: $\mathrm{p}$ - significant of differences in relation to intact animals.

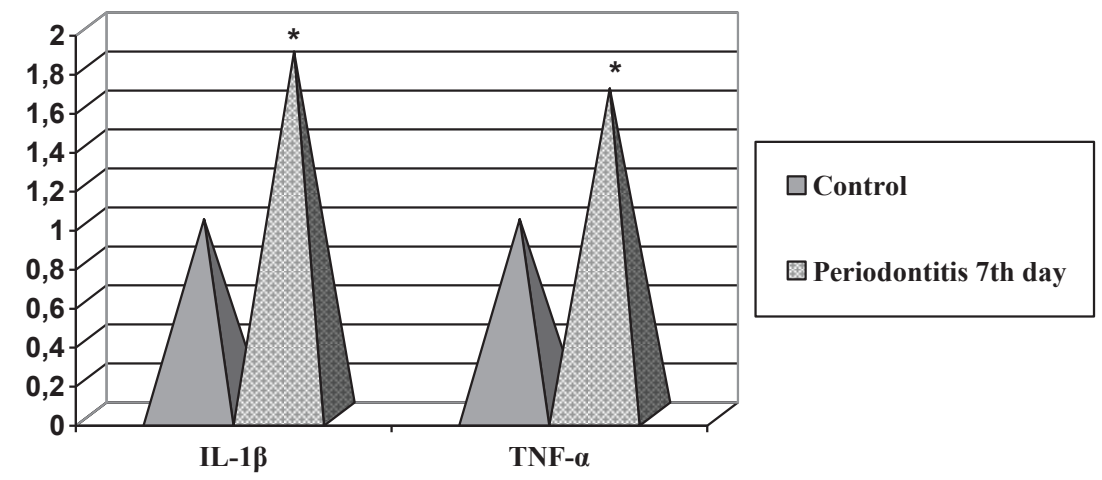

Figure 1. Dynamics of proinflammatory cytokines content in blood serum of white rats with experimental periodontitis (times, relative to control). Notes: * - significant of differences in relation to the intact animals $(p<0.01)$. 


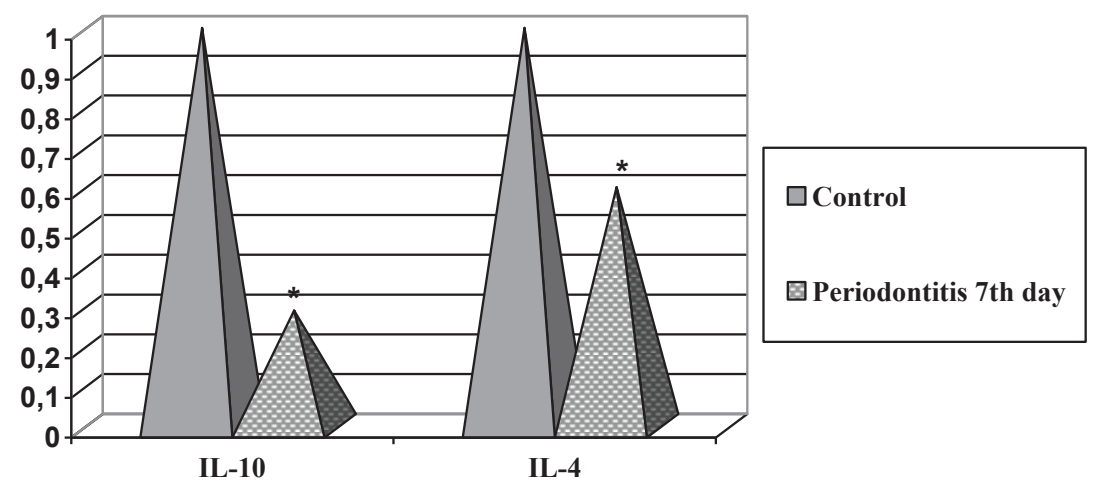

Figure 2. Dynamics of the anti-inflammatory cytokines content in the rat's blood serum with experimental periodontitis (times, relative to control). Notes: * - significant of differences in relation to the intact animals $(p<0.01)$.

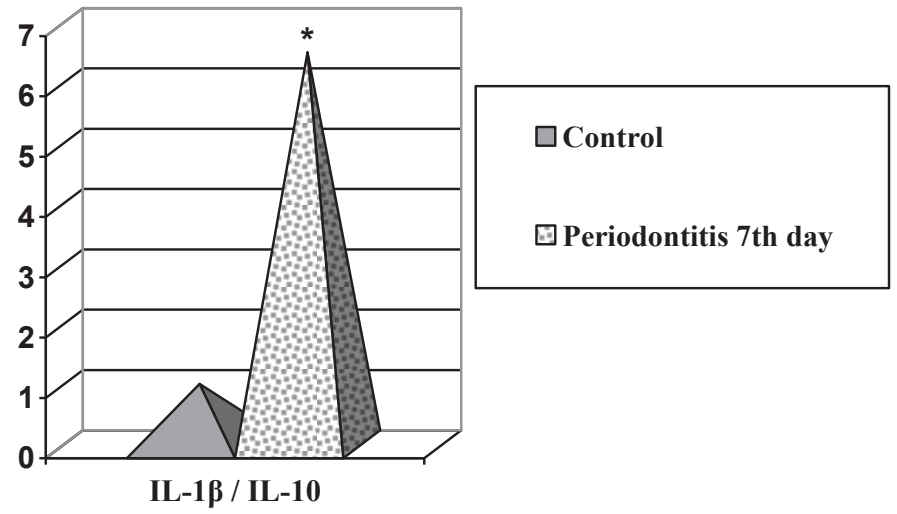

Figure 3. Dynamics of proinflammatory and anti-inflammatory cytokines ratio in the rats with experimental periodontitis (times, relative to control). Notes: ${ }^{*}$ - significant of differences in relation to the intact animals $(p<0.01)$.

characterized by reliable progressive increase of proinflammatory cytokines for the early stage of inflammatory reaction development, that prove participation of TNF- $\alpha$ and IL-1 $\beta$ in the periodontal diseases pathogenesis.

\section{LITERATURE}

1. Мозгова Л. А. Ефективність лікування хронічного генералізованого пародонтиту з використанням інфрачервоного лазерного світла / Л. А. Мозгова, Д. В. Шмідт, А. Ю. Новиков // Стоматологія. - 2011. - № 6. - С. 11-16.

2. Role of complement in host-microbe homeostasis of the periodontium / G. Hajishengallis, T. Abe, T. Maekawa [et al.] // Semin. Immunol. - 2013. - Vol. 25, No. 1. - P. 65-72.

3. Demkovych A. Ye. (2018). Changes of antioxidant potential under the experimental periodontitis development / A. Ye. Demkovych, Yu. I. Bondarenko // Фізіологічний журнал. - 2018. - Т. 64, № 3. - C. 43-51.

4. Demkovych A. Ye. Oxidative modification of proteins in the process of experimental periodontitis development / A. Demkovych, Yu. Bondarenko, P. A. Hasiuk // Interventional Medicine and Applied Science. - 2017. - Vol. 9, No. 4. - P. 218-221.

5. Duvina M. Biochemical markers as predictors of bone remodelling in dental disorders: a narrative description of literature // M. Duvina, L. Barbato // Clin. Cases Miner Bone Metab. - 2012. - Vol. 9 (2). - P. 100-106.

6. Combination with allogenic bone reduces early absorption of beta- tricalciumphosphate (beta- TCP) and enhances the role as a bone regeneration scaffold: experimental animal study in rat mandibular bone defects / M. Hirota, Y. Matsui, N. Mizuki [et al.] // Dent. Mater J. - 2009. - Vol. 28. - P. 153-161.
2. For the experimental bacterial-immune periodontitis (on the $7^{\text {th }}$ day of the research) the level of anti-inflammatory cytokines in the animal serum blood, in particular IL-10 and IL-4, decreases, indicating their insufficiency in the regulation of the immune-inflammatory response in this modeled pathology.

7. Liu Y. C. Cytokine responses against periodontal infection: protective and destructive roles / Y. C. Liu, U. H. Lerner, Y. T. Teng // Periodontol. - 2000. - Vol. 52. - P. 163-206.

8. Deo V. Pathogenesis of periodontitis: role of cytokines in host response / V. Deo, M. L. Bhongade // Dent Today. - 2010. - Vol. 29 (9). - P. 60-62; 64-66.

9. Periodontitis and bone metabolism / L. Barbato, E. Francioni, M. Bianchi [et al.] // Clin. Cases Miner Bone Metab. - 2015. Vol. 12 (2). - P. 174-177.

10. Демкович А. Є. Патогенетичні основи моделювання пародонтиту у тварин / А. Є. Демкович, Ю. І. Бондаренко // Здобутки клінічної і експериментальної медицини. - 2015. - № 1 (22). - С. 54-57.

11. Сенников С. В. Методы опредиления цитокинов / С. В. Сенников, А. Н. Силков // Цитокины и воспаление. - 2005. - T. 4, № 1. - C. 22-27.

12. Орлов А. И. Математика случая: Вероятность и статистика - основные фракты: учебное пособие / А. И. Орлов. - М. : M3-Пресс, 2004. - 100 c.

13. Berger. R. L. Statistical Inference $2^{\text {nd }}$ ed / R. L. Berger., G. Casella. - Florida: Duxbury Press. - 2001. - 374 p.

14. Endothelin-1 stimulates proinflammatory cytokine expression in human periodontal ligament cells via mitogen-activated protein 
kinase pathway / L. Liang, J. Yu, W. Zhou [et al.] // J. Periodontol. - 2014. - Vol. 85, No. 4. - P. 618-626.
15. Wilson E. B. The role of IL-10 in regulating immunity to persistent viral infections / E. B. Wilson, D. G. Brooks // Curr. Top Microbiol. Immunol. - 2011. - No. 350. - P. 39-65.

Received 15.08.18

Email for correspondence: demkovych.andrii@gmail.com

(СА. Є. Демкович, Ю. І. Бондаренко, К. Є. Юріїв Двнз “Тернопільський державний медичний університет імені І. Я. Горбачевського"

\section{ЦИТОКІНОВІ МЕХАНІЗМИ В РАННЬОМУ ПЕРІОДІ РОЗВИТКУ ЕКСПЕРИМЕНТАЛЬНОГО БАКТЕРІАЛЬНО-ІМУННОГО ПАРОДОНТИТУ}

Резюме. У статті наведено результати досліджень показників цитокінового профрілю як посередника імунного захисту, що визначали за рівнем прозапальних та протизапальних цитокінів у сироватці крові інтактних тварин та на 7-му добу розвитку експериментального бактеріально-імунного пародонтиту. Звертають увагу на характерну зміну показників цитокінової ланки імунітету на ранньому етапі розвитку експериментального пародонтиту. Зокрема, у період гострих проявів запальної реакції на 7-му добу дослідження відбувалося підвищення у сироватці крові концентрації IL-1 $\beta$ та THF- $\alpha$, а вміст IL-10, IL-4 за даних умов зменшувався. При цьому співвідношення про- та протизапальних цитокінів (IL-1ß/IL-10), як важливий показник імунної реакції, значно підвищувався. На підставі даних результатів було доведено, що формування патологічного процесу в пародонтальному комплексі супроводжується дисбалансом у системі цитокіногенезу вже в ранній період розвитку запальної реакції, що свідчить про їх модулювальну роль у регуляції імунно-запальної відповіді при даному модельованому патологічному процесі.

Мета дослідження - визначити патогенетичну роль цитокіногенезу на ранніх стадіях експериментального розвитку бактеріально-імунного пародонтиту.

Матеріали і методи. Дослідження проводили з використанням білих клінічно здорових щурів-самців масою тіла 150-200 г в умовах віварію. Експериментальних тварин відібрали та поділили на дві експериментальні групи: перша група - здорові тварини, контроль; друга група - тварини з експериментальним періодонтитом на 7-й день.

Результати досліджень та їх обговорення. Експериментальний бактеріально-імунний пародонтит у дослідних тварин викликали введенням у тканину комплексу пародонта суміші мікроорганізмів, розбавлених яєчним білком. Щоб зміцнити імунну відповідь, одночасно проводили ін'єкцію у кінцівку щура ад'юванта Фрейнда. Досліджували сироватку крові, в якій визначали

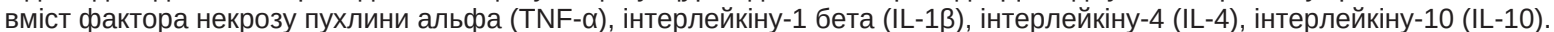
Висновки. Формування експериментального пародонтиту супроводжується комплексом патологічних змін, що характеризуються надійним прогресуючим зростанням прозапальних цитокінів на ранній стадії розвитку запальних реакцій, що підтверджує участь TNF- $\alpha$ та IL-1 $\beta$ у патогенезі захворювань пародонта.

Ключові слова: бактеріально-імунний пародонтит; імунна система; запалення; запальні цитокіни; протизапальні цитокіни.

(ㄱ.. Е. Демкович, Ю. И. Бондаренко, Е. Е. Юриив ГВУз “Тернопольский государственный медицинский университет имени И. Я. Горбачевского”

\section{ЦИТОКИНОВЫЕ МЕХАНИЗМЫ В РАННИЙ ПЕРИОД РАЗВИТИЯ ЭКСПЕРИМЕНТАЛЬНОГО БАКТЕРИАЛЬНОЙ-ИММУННОГО ПАРОДОНТИТА}

Резюме. В статье приведены результаты исследований показателей цитокинового профиля в качестве посредника иммунной защиты, которые определяли по уровню провоспалительных и противовоспалительных цитокинов в сыворотке крови интактных животных и на 7-е сутки развития экспериментального бактериально-иммунного пародонтита. Обращают внимание на характерное изменение показателей цитокинового звена иммунитета на раннем этапе развития экспериментального пародонтита. В частности в период острых проявлений воспалительной реакции на 7-е сутки исследования происходило повышение в сыворотке крови концентрации IL-1 $\beta$ и THF- $\alpha$, а содержание IL-10, IL-4 при данных условиях уменьшался. При этом соотношение про- и противовоспалительных цитокинов (IL-1ß/IL-10), как важный показатель иммунной реакции, значительно повышался. На основании данных результатов было доказано, что формирование патологического процесса в пародонтальном комплексе сопровождается дисбалансом в системе цитокиногенеза уже на ранних этапах развития воспалительной реакции, что свидетельствует об их модулирующий роли в регуляции иммунно-воспалительного ответа при данном моделируемом патологическом процессе.

Цель исследования - определить патогенетическую роль цитокиногенеза на ранних стадиях экспериментального развития бактериально-иммунного пародонтита.

Материалы и методы. Исследования проводились с использованием белых клинически здоровых крыс-самцов весом тела 150-200 г в условиях вивария. Экспериментальных животных отобрали и разделили на две экспериментальные группы: первая группа - здоровые крысы, контроль; вторая группа - животные с экспериментальным периодонтитом на 7-й день.

Результаты исследований и их обсуждение. Экспериментальный бактериально-иммунный пародонтит у опытных животных был вызван введением в ткань комплекса пародонта смеси микроорганизмов, разбавленных яичным белком. Чтобы укрепить иммунный ответ, одновременно проводили инъекцию в лапу крысы адъюванта Фрейнда. Исследовали сыворотку крови, в которой определяли содержание фрактора некроза опухоли альфа (TNF- $)$ ), интерлейкина-1-бета (IL-1ß), интерлейкина-4 (IL-4), интерлейкина-10 (IL-10). Выводы. Формирование экспериментального пародонтита сопровождается комплексом патологических изменений, характеризующихся надежным прогрессирующим ростом провоспалительных цитокинов на ранней стадии развития воспалительных реакций, подтверждающий участие TNF- $\alpha$ и IL-1ß в патогенезе заболеваний пародонта.

Ключевые слова: бактериально-иммунный пародонтит; иммунная система; воспаление; воспалительные цитокины; противовоспалительные цитокины. 